\title{
Gestational Pruritus: Irritation more than Itching
}

\author{
Pankaj Srivastava $^{1^{*}}$, Shalini Srivastava ${ }^{2}$ \\ ${ }^{1}$ Department of Surgery, Om Surgical Center \& Maternity Home, Varanasi, India \\ ${ }^{2}$ Departments of Obs \& Gyn, Om Surgical Center \& Maternity Home, Varanasi, India
}

*Corresponding author: Pankaj Srivastava, Laparoscopic, Thoracic, Thoracoscopic \& VATS Surgeon Om Surgical Center \& Maternity Home SA 17 / 3, P-4, Sri Krishna Nagar, Paharia, Ghazipur Road, Varanasi, UP, INDIA. PIN-221007, Tel: +91-542-2586191 / +919415226817; Email: drpankajbns@gmail.com

Pruritus can affect up to $20 \%$ of pregnant patients ${ }^{[1,2]}$. It may disturb sleep, mood, or even cause depression and can be a great cause of discomfort to the pregnant patients ${ }^{[3]}$. Clinical history and physical examination are very important in evaluating the causes of pruritus added by investigations. Conditions specific to pregnancy involving pruritus as a leading symptom are summarized in Table 1.

Table 1: Differential Diagnosis of Gestational Pruritus

\begin{tabular}{|l|l|}
\hline 1. & Intrahepatic cholestasis of pregnancy \\
\hline 2. & PUPPP (Pruritic urticarial papules and plaques of pregnancy) \\
\hline 3. & Pemphigoid gestationis \\
\hline 4. & Atopic eruptions of pregnancy \\
\hline 5. & Impetigo herpeteformis \\
\hline 6. & Pruritic folliculitis of pregnancy \\
\hline 7. & Prurigo of pregnancy \\
\hline
\end{tabular}

Intra hepatic cholestasis of pregnancy (ICP) is also called as idiopathic jaundice of pregnancy, obstetric cholestasis, icterus gravidarum, obstetric hepatosis, and pruritus gravidarum. It affects $0.7 \%$ to $5 \%$ of pregnancy in multiethnic population ${ }^{[4]}$. Prevalence of ICP is influenced by genetic and environmental factors. It is a multi factorial condition of pregnancy characterized by pruritus in the absence of a skin rash with abnormal liver function tests (LFTs), neither of which has an alternative cause and both of which resolve after birth. Most authorities accept elevations of any of a wide range of LFTs beyond pregnancy specific limits ${ }^{[5]}$. It is caused by disruption of hepatic bile flow during pregnancy, a condition triggered by hormones in genetically predisposed females who have a defect in excretion of bile acids resulting in elevated bile acid levels in the serum. This causes intense pruritus in mother. Pruritus is evidenced in absence of skin rash with abnormalities of liver function test (LFT) beyond pregnancy specific limits. Pruritus affecting palms and soles is particularly suggestive but later on more or less generalized. In ICP level of total serum bile acid more than $40.0 \mu \mathrm{mol} /$ $\mathrm{L}$ is associated with high risk of adverse fetal outcome. The toxic bile acids can pass in fetal circulation causing placental anoxia and cardiac depression leading to fatal fetal complications like spontaneous or iatrogenic preterm birth $^{[6]}$, meconium passage ${ }^{[7]}$, fetal distress ${ }^{[8]}$, and fetal death ${ }^{[5,7]}$.

Maternal complications are mood or sleep disturbance, intrapartum and postpartum hemorrhage. The risk factors are previous or family history of obstetric cholestasis, multiple pregnancies, hepatitis $\mathrm{C}$, gallstones, and drugs. To detect abnormalities in liver function test, the upper limit of normal throughout pregnancy is $20 \%$ lower than the non-pregnant range for transaminases, gammaglutamyl transferase and bilirubin ${ }^{[9]}$. In healthy pregnancies, total serum bile acid levels in the third trimester of up to $11.0 \mu \mathrm{mol} / \mathrm{L}$ are accepted as normal. Jaundice may occur in few patients due to concomitant extra hepatic cholestasis. Weekly monitoring of LFT is recommended. In patients with such a presentation, a battery of test is further required to differentiate it from other liver disorders like screening for hepatitis A,B,C; Ebstein Barr virus, cytomegalovirus, chronic active hepatitis, primary biliary cirrhosis, gallstones, preeclampsia, and acute fatty liver of pregnancy. In severe cases, prothrombin time assessment should be done. Treatment aims to decrease liver enzymes and bile acids, and to relieve maternal pruritus. By improving maternal condition, the fetal outcome is improved. Treatment includes topical emollients, which cause just slight temporary relief of pruritus; antihistamines like chlorphineramine; ursodeoxycholic acid (UDCA) which decreases liver transaminases, and bile acid levels in a dose of $15 \mathrm{mg} / \mathrm{kg}$ daily until delivery of baby; vitamin $\mathrm{K}$ in dose of $5-10 \mathrm{mg} /$ day is advised if prothrombin time is prolonged. Vitamin $\mathrm{K}$ should be avoided in late pregnancy and labor because of a risk of neonatal hemolytic anemia, hyperbilirubinemia and kernicterus. Pregnant women taking antiepileptic medications (who are at risk of vitamin $\mathrm{K}$ deficiency because of liver enzyme induction) show greater levels of vitamin $\mathrm{K}$ in the offspring of those who took oral supplements before delivery compared with the offspring of those who did not ${ }^{[10]}$.

Fetal complications especially still births are more frequent after 37 weeks so induction should be considered after 37

\author{
Received date: April 22, 2018 \\ Accepted date: April 30, 2018 \\ Publish date: May 7, 2018
}

Citation: Pankaj, S., et.al. Gestational Pruritus: Irritation More Than Itching (2018) J Gastrointest Disord Liver Func 4(1): 4- 5.

Copy Rights: (C) 2018 Pankaj, S. This is an Open access article distributed under the terms of Creative Commons Attribution 4.0 International License. 
weeks particularly in patients with serum bile acids more than 40 $\mu \mathrm{mol} / \mathrm{L}$. Even close fetal monitoring in ICP is not effective in preventing fetal death. This condition regresses spontaneously within days to weeks after delivery but can recur with subsequent pregnancies or with use of hormonal contraception. Patient should be counseled properly so that her mood disturbance and her anxiety can be avoided.

Conclusively, high index of suspicion, appropriate laboratory investigations, judicious use of medicines and close vigilance on pregnancy lead to best fetal outcome with least maternal complication.

\section{References}

1. Wong, R.C., Ellis, C.N. Physiologic skin changes in pregnancy. (1984) J Am Acad Dermatol 10(6): 929-940

Pubmed | Crossref $\mid$ others

2. Rook, A., Wilkinson, D.S., Ebling, F.J., Textbook of dermatology. $3^{\text {rd }}$ ed. (1979) Oxford, Engl: Blackwell Scientific Publications $180-181$.

Pubmed $\mid$ Crossref $\mid$ Others

3. Moses, S. Pruritus. (2003) Am Fam Physician 68(6):11351142 .

Pubmed $\mid$ Crossref $\mid$ Others

4. RCOG Green-top Guideline No.43. (2011)

Pubmed $\mid$ Crossref $\mid$ Others

5. Girling, J.C., Dow, E., Smith, J.H. Liver function tests in preeclampsia: importance of comparison with a reference range derived for normal pregnancy. (1997) Br J Obstet Gynaecol104: 246-250.

\section{Pubmed $\mid$ Crossref $\mid$ Others}

6. David, A.L., Kotecha, M., Girling, J.C. Factors influencing postnatal liver function tests. (2000) BJOG 107: 1421-1426.

\section{Pubmed | Crossref $\mid$ Others}

7. Reyes, H., Gonzalez, M.C., Ribalta, J., et al. Prevalence of intrahepatic cholestasis of pregnancy in Chile. (1978) Ann Intern Med 88: 487-493.

Pubmed |Crossref | Others

8. Rioseco, A.J., Ivankovic, M.B., Manzur, A., et al. Intrahepatic cholestasis of pregnancy: a retrospective case-control study of perinatal outcome. (1994) Am J Obstet Gynecol 170:890-895.

\section{Pubmed | Crossref $\mid$ Others}

9. Shaw, D., Frohlich, J., Wittman, B.A., et al. A prospective study of 18 patients with cholestasis of pregnancy. (1982) Am J Obstet Gynecol 142(6): 621-625.

\section{Pubmed |Crossref | Others}

10. Cornelissen, M., Steegers-Theunissen, R., Kollée, L., et al. Supplementation of vitamin $\mathrm{K}$ in pregnant women receiving anticonvulsant therapy prevents neonatal vitamin $\mathrm{K}$ deficiency. (1993) Am J Obstet Gynecol 168: 884-888.

Pubmed | Crossref | Others
Submit your manuscript to Ommega Publishers and we will help you at every step:

- We accept pre-submission inquiries

- Our selector tool helps you to find the most relevant journal

- We provide round the clock customer support

- Convenient online submission

- Thorough peer review

- Inclusion in all major indexing services

- Maximum visibility for your research

Submit your manuscript at OMMEgA Publishers https://www.ommegaonline.org/submit-manuscript 